This is the peer reviewed version of the following article: Smales, L. and Kininmonth, J. 2016. FX Market Returns and Their Relationship to Investor Fear. International Review of Finance. 16 (4): pp. 659-675, which has been published in final form at http://doi.org/10.1111/irfi.12083 This article may be used for non-commercial purposes in accordance with Wiley Terms and Conditions for SelfArchiving at http://olabout.wiley.com/WileyCDA/Section/id-828039.html 


\section{FX market returns and their relationship to investor fear}

\section{Author Details:}

**L.A. Smales, School of Economics \& Finance, Curtin University, Australia

J.N. Kininmonth, School of Economics \& Finance, Curtin University, Australia

**Corresponding Author

\section{Abstract:}

This note examines the relationship between changes in levels of investor fear (measured by VIX) and FX market returns. Our empirical results indicate a negative relationship between daily returns on high-interest rate (investing) currencies and changes in VIX, while the association is positive for low-interest rate (funding) currencies. That is, investing (funding) currencies tend to depreciate (appreciate) when investor fear increases. A sequential breakpoint test identifies a significant change in this relationship in the period following the 2008 collapse of Lehman Brothers, and another in 2012 following the European sovereign debt crisis. During this crisis period, currency returns are much more sensitive to changes in investor fear, and this is particularly so for funding currencies which are perceived to be a safe-haven. 


\section{FX market returns and their relationship to investor fear}

\section{Introduction}

With daily turnover exceeding $\$ 5$ trillion $^{1}$, the foreign exchange market is the largest financial market. In addition to the historic function of facilitating international trade and capital flows, today a large proportion of transactions are enacted in order to speculate on movements in exchange rates. The carry-trade is one of the most popular investment strategies; borrowing in currencies with low interest rates (the funding currency) and investing the proceeds in currencies with high interest rates (the investing currency). According to uncovered interest rate parity, this strategy should be unprofitable since movements in exchange rates will offset any gain arising from the interest rate differential across countries. However, empirical evidence, together with the prevalence of informed investors (such as hedge funds) engaging in such strategies, suggests that in fact the opposite is true; on average investment currencies tend to appreciate, while funding currencies depreciate. Fama (1984) refers to this as the "forward premium puzzle".

There is empirical evidence of a relationship between returns in stock markets and foreign exchange markets. For instance, Tse and Zhao (2012) find a strong correlation between daily returns of currency carry trades and U.S. stocks over the period 1995-2010. They suggest that this relationship exists because both reflect the risk appetite of investors. The S\&P500 implied volatility index (VIX) has been utilized as a proxy for the level of investor risk aversion or market sentiment (Brunnermeier et al., 2008; Bekaert et al., 2013), and the negative relationship with stock returns is well documented (Giot, 2005; Whaley, 2009). A comparable relationship is identified in foreign exchange markets. For instance, Ranaldo and Söderlind (2010) note that safe-haven currencies, such as the Swiss franc and Japanese yen, appreciate when stock market volatility increases. Similarly, Lustig et al. (2011) identify a slope factor that is related to changes in equity market volatility, and has a greater impact on high interest rate currencies. While Fong (2013) suggests that optimism in the stock market, indicated by a low VIX, induces increased hedge fund speculation, and higher returns, in the currency market.

Since changes in interest rates effect returns in both stock and currency markets, it is possible that changes in monetary policy provide an explanation for the association between changes in VIX and market returns. Vähämaa and Äijö (2011) show that VIX is significantly affected by the Fed's policy decisions. Bekaert et al. (2013) state that VIX co-moves with the monetary policy stance, and has a strong positive correlation with real interest rates. While Kurov (2010) finds that the effect of monetary policy on implied volatility depends on market conditions.

\footnotetext{
${ }^{1}$ Bank of International Settlements' Triennial Central Bank Survey of foreign exchange and derivatives market activity (http://www.bis.org/publ/rpfx13.htm)
} 
This suggests that the relationship between VIX and currency returns may be state dependant. Indeed, the literature suggests that the relationship becomes stronger during periods of high volatility (Lustig et al., 2011; Tse and Zhao, 2012) or financial crisis (Ranaldo and Söderlind, 2010; Lin, 2012). Menkhoff et al. (2012) report that high-interest (low-interest) currencies depreciate (appreciate) when volatility is unexpectedly high. While Ranaldo and Söderlind (2010) expand on this apparent safehaven status of funding currencies during crisis, and note that the effects on the yen are particularly discernible. Brunnermeier et al. (2008) suggest that this is a result of the funding constraints on speculators, which become more important during times of financial dislocation, and results in the unwinding of carry trade positions. The change in relationship may also be a result of VIX responding to financial news differently in periods of market turmoil (Smales, 2014).

This note seeks to expand our understanding on the relationship between market sentiment or investor fear (measured by VIX) and returns in the foreign exchange markets. We hope to answer two related questions: First, does the relationship between VIX and currency returns depend on whether the currency is a funding (low interest rate) or an investing (high interest rate) currency? Second, does financial crisis affect this relationship, and how? Understanding behaviour in the foreign exchange market is important in pricing, hedging, and trading, and has implications for international trade in addition to financial market participants.

Our empirical results indicate a negative relationship between daily returns on investing currencies and changes in VIX, thus investing currencies depreciate (appreciate) when investor fear increases (decreases). The reverse is true for funding currencies (and the USD). Consistent with Lustig et al. (2011), changes in VIX appear to have a greater impact on investing currencies. A sequential breakpoint test identifies a significant change in this relationship in the period following the 2008 collapse of Lehman Brothers, and another in 2012 (we speculate this follows a resolution of sorts to the European sovereign debt crisis). During this crisis period, currency returns are much more sensitive to changes in investor fear, and this is particularly so for funding currencies, which aligns with the safe-haven properties noted by Ranaldo and Söderlind (2010).

\section{Data}

We investigate the relationship between the fear gauge and returns in the foreign exchange futures market using daily settlement prices for futures contracts traded in Chicago.

\section{Implied Volatility Index (VIX)}

The Chicago Board Options Exchange (CBOE) implied volatility index (VIX) estimates the level of implied volatility in S\&P 500 index (SPX) options. VIX is computed on a real-time basis by averaging the weighted prices of SPX puts and calls over a wide range of strike prices, and represents expected market volatility over the next 30 calendar days. The VIX is quoted in percentage points and 
translates, approximately, to the expected movement in the S\&P 500 Index over the next 30-day period, which is then annualized. For example, if VIX is 20, this represents an expected annualized change of $20 \%$ over the next 30 days; thus one can infer that the options market expects the S\&P 500 index to move up / down by $5.77 \%(20 \% / v 12)$ over the next 30-day period. Portfolio insurers, who routinely buy index puts are the largest constituents of the S\&P 500 Index option market; hence, it is likely that it is put buyers who help to drive changes in implied volatility (VIX) and provides the index with the colloquial term - the "fear gauge" (Whaley, 2000). By interpreting VIX in this way, we are able to use it as a proxy for market sentiment.

We obtain daily settlement prices for VIX futures ${ }^{2}$, traded on the CBOE, from DataStream for the period 26 March 2004 (the first day of this contract trading) until 31 December 2014. Table 1 provides summary statistics for VIX; the mean level over the whole sample period is 20.95 , with a peak of 80.86 occurring in October 2008 (the peak of the financial crisis), and a low of 9.89 in January 2007. The average daily return in VIX futures (calculated as $100 * \ln \left(\mathrm{P}_{t} / \mathrm{P}_{\mathrm{t}-1}\right)$ is -0.007 .

\section{Foreign Exchange (FX) Futures}

We obtain daily settlement prices for a range of FX futures ${ }^{3}$ from DataStream, choosing a period that coincides with the availability of VIX futures (i.e. from March 2004 - December 2014). FX futures are traded on the Chicago Mercantile Exchange (CME), while U.S. dollar index futures (DX) are traded on the Intercontinental Exchange (ICE). We follow the CME in grouping FX futures into 'Major' ${ }^{4}$ and 'Emerging Market' ${ }^{5}$ currencies $^{6}$. We further classify major currencies as highyielding (investment) or low-yielding (funding) currencies on the basis of their average 10-year interest rate swap rate over the sample period ${ }^{7}$. All FX futures contracts are quoted as units of U.S. Dollar (USD) per 1 unit of quoted currency. A series of daily returns is calculated for the sample period $\left(100 * \ln \left(\mathrm{P}_{t} / \mathrm{P}_{\mathrm{t}-1}\right)\right)$, and a negative (positive) return indicates depreciation (appreciation) of the quoted currency. Summary statistics are provided in Table 1.

\section{Empirical Results}

\section{Relationship between VIX and FX futures}

\footnotetext{
${ }^{2}$ The value of one VIX futures contract is equal to $\$ 1,000 \mathrm{x}$ the index value.

${ }^{3}$ The value of one FX futures contract is equal to 100,000 units of the foreign (non-USD) currency, while the DX futures have a contract value of $\$ 1,000 \mathrm{x}$ the index value.

${ }^{4}$ The major currencies are Australian Dollar (AUD), Canadian Dollar (CAD), Euro (EUR), Great Britain Pound (GBP), Norwegian Krona (NOK), New Zealand Dollar (NZD), Swedish Krona (SEK), Swiss Franc (CHF), Japanese Yen (JPY), and US Dollar (USD).

${ }^{5}$ The emerging market currencies are Brazilian Real (BRL), Czech Koruna (CZK), Hungarian Forint (HUF), Israeli Shekel (ILS), Korean Won (KRW), Mexican Peso (MXN), Polish Zloty (PLN), Chinese Renminbi (RMB), Russian Ruble (RUB), and the South African Rand (ZAR).

${ }^{6}$ Contracts on major currencies have traded on the CME throughout the sample period, while the number of emerging market currencies has gradually increased over time.

${ }^{7}$ On this basis, CHF and JPY are determined to be funding currencies.
} 
We are interested in understanding how levels of market sentiment (proxied by VIX) relate to returns in currency markets (which we approximate using FX futures). Figure 1 illustrates that for currencies classified as major investment, or emerging market, there is sharp depreciation in the quoted (non-U.S.) currency when investor fear spikes. For the major funding currencies (CHF, and JPY), and to a lesser extent for the USD Index, the reverse is true; they sharply appreciate whenever VIX jumps higher - there is a particularly prominent appreciation in CHF when VIX jumps during the sovereign debt crisis of 2011. This would be consistent with higher levels of market uncertainty, or perceived risk, causing a flight to quality. Alternatively, this could be a result of increased risk resulting in tighter credit that in turn forces market participants to close out large positions in carrytrades.

\section{$<$ Insert Figure 1 >}

We investigate this relationship more formally using a simple regression model of the form:

$$
R_{j, t}=\beta_{0}+\beta_{1} R V I X_{t}+\varepsilon_{t}
$$

Where $R_{j, t}$ is the return on the FX future for currency $j$ on day $t, R V I X_{t}$ is the return on the VIX future on day $t$, and $\varepsilon_{\mathrm{t}}$ is the heteroscedasticity-consistent (Newey-West) standard error. The results for the whole sample period are presented in Table 2. For all currencies classified as major investing currencies, the relationship is negative and significant. We interpret this as depreciation in those currencies (alternatively, this may be viewed as an appreciation in the USD) on days when market sentiment declines (VIX increases). The magnitude of the coefficient, and the fit of the model (adj. $\mathrm{R}^{2}$ ) is greatest for the three currencies (NZD, AUD, NOK) who had the highest interest rates on average over the sample period. Such currencies would most likely be targeted by investors looking to engage in the carry-trade, and as such may be more likely to experience speculative flows that are influenced by market sentiment.

The same relationship is also reported for emerging market currencies, with negative coefficients and currencies with the highest average interest rate (BRL, ZAR, HUF) exhibiting the greatest response to changes in VIX. Ex-ante we expected that the magnitude of the relationship may be greater for emerging market currencies given the higher level of risk entailed with investing in such currencies, but there is no significant difference in the coefficients. The Chinese Renminbi (RMB) is the only currency with a significant coefficient for the constant term, and also has the smallest coefficient for the explanatory variable; this is likely due to the managed float exchange rate regime adopted by the Chinese monetary authorities.

For the funding currencies, and the USD Index, the indicated relationship is different. The coefficient for the explanatory variable is positive and well-defined, indicating that funding currencies 
appreciate as investor fear increases. This suggests that the CHF, JPY, and USD act as safe havens when market sentiment declines.

It is possible that our results are driven purely by changes in the USD. Certainly, this will be a contributing factor; however we suspect that this is not the whole story. First, the graphical evidence (Figure 1) suggests that sharp movements in specific currencies coincide with changes in VIX that do not necessarily result in changes in the USD index. Second, empirical evidence reported in Table 2 suggests that the negative relationship is limited only to major investment currencies and emerging market currencies. This would support the notion that the relationship is a result of a flight to quality, or closing of carry-trade positions.

\section{$<$ Insert Table 2>}

\section{Identifying breakpoints in the relationship}

If the response of investment currencies, and funding currencies, to changes in market sentiment is related to their perceived status as safe-haven currencies then we might expect the relationship to become stronger during periods of great financial stress, which coincide with sharp increases in investor fear. Many papers choose the collapse of Lehman Brothers $\left(15^{\text {th }}\right.$ September 2008) as the starting point of the global financial crisis. Alternative suggestions could include problems within Bear Sterns hedge funds that focused on collateralized debt obligation (June 2007), suspension of redemption from Bear Sterns' subprime funds (August 2007), or the collapse of Bear Sterns (March 2008). We empirically test for the appropriate starting point by searching for break points in the relationship between changes in market sentiment (which we proxy with VIX) and returns on FX futures.

Using well-established sequential breakpoint tests (Bai, 1997; Bai and Perron, 1998) with heteroscedasticity-consistent (Newey-West) standard errors, we are able to identify two breakpoints for each FX future. Table 3 summarises the breakpoints for each FX future. For a substantial proportion of currencies the first breakpoint is within the period $15^{\text {th }}-30^{\text {th }}$ September, within 2-weeks of the Lehman collapse. The second breakpoint for each currency occurs in the period May September 2012. While we are hesitant to specify an event that directly caused this break, we may speculate that it relates to a resolution to the European sovereign debt crisis (for instance, August 2012 witnessed the completion of the $2^{\text {nd }}$ bailout package for Greece).

$<$ Insert Table 3>

\section{Influence of Global Financial Crisis}

We repeat our analysis, concentrating on the period of the Global Financial Crisis (GFC). Based on the analysis of structural breaks, we choose $15^{\text {th }}$ September 2008, the day of the Lehman 
Brothers collapse as the start point, and 03 August 2012 as the end date ${ }^{8}$. While this is period is longer than that specified elsewhere, it is consistent with an extended period of heightened investor fear as the GFC intersected with the European sovereign debt crisis. The estimated coefficients are reported in Table 4.

The sign of the relationship remains the same for all currencies, negative and statistically significant for major investing and emerging market currencies, and positive for major funding currencies. More importantly, the magnitude of the response to changes in market sentiment sharply increases during the period of the global financial crisis. On average, the estimated coefficient is twice the size during this period as it is during the whole sample, and the difference is statistically significant. Interestingly, the largest increase in the coefficient occurs in CHF, JPY, and USD (the average increase for these currencies is $3.38 \mathrm{x}$ ) - consistent with the argument that these act as safehavens during periods of market turmoil (when VIX is at elevated levels).

\section{$<$ Insert Table 4>}

We may infer from the results that the onset of financial crisis produced extreme levels of market uncertainty that caused a change in the relationship between market sentiment and returns on FX futures. At this time, returns in FX markets apparently became more sensitive to changes in market sentiment. This regime remained in place until the global financial crisis, and the ensuing sovereign debt crisis, passed and market sentiment returned to levels viewed as historically normal.

\section{Conclusion}

There is a statistically significant link between changes in market sentiment and returns in the FX futures market. As market sentiment declines (investor fear increases) major investing currencies, and emerging market currencies, tend to depreciate. The magnitude of this depreciation is positively related to the level of interest rates in the quoted currency, so the highest yielding currencies (which tend to have more speculators chasing the carry-trade) tend to depreciate more. On the other hand, currencies such as CHF, JPY, and USD (which are often used as funding currencies in the carry-trade speculation) appear to act as a safe haven and appreciate when market sentiment declines. The results are more pronounced during the global financial crisis, when investor fear sharply increases, and credit conditions tighten considerably.

\section{References}

Bai, J., 1997, Estimating multiple breaks one at a time, Econometric Theory, 13, 315-352

\footnotetext{
${ }^{8}$ As a robustness test, we repeat our analysis for a number of sample end dates occurring in the second breakpoint interval and find that the results are qualitatively similar.
} 
Bai, J., and P. Perron, 1998, Estimating and testing linear models with multiple structural changes, Econometrica, 66, 47-78

Bekaert, G., M. Hoerova, and M.L. Duca, 2013, Risk, uncertainty and monetary policy, Journal of Monetary Economics, 60, 771-788

Brunnermeier, M.K., S. Nagel, and L.H. Pedersen, 2008, Carry trades and currency crashes, NBER Macroeconomics Annual, 23, 313-347

Fama, E.F., 1984, Forward and spot exchange rates, Journal of Monetary Economics, 14, 319-338

Fong, W.M., 2013, Footprints in the market: Hedge funds and the carry trade, Journal of International Money and Finance, 33, 41-59

Giot, P., 2005. Relationships between implied volatility indexes and stock index returns. J. Portfolio Management 26, 12-17

Kurov, A., 2010, Investor sentiment and the stock market's reaction to monetary policy, Journal of Banking \& Finance, 34, 139-149

Lin, C.H., 2012, The comovement between exchange rates and stock prices in the Asian emerging markets, International Review of Economics \& Finance, 22, 161-172

Lustig, H., N. Roussanov, and A. Verdelhan, 2011, Common risk factors in currency markets, Review of Financial Studies, 24, 3731-3777

Menkhoff, L, L. Sarno, M. Schmeling, and A. Schrimpf, 2012, Carry trades and global foreign exchange volatility, Journal of Finance, 67, 681-718

Ranaldo, A., and P. Söderlind, 2010, Safe haven currencies, Review of Finance, 14, 385-407

Smales, L.A., 2014, News sentiment and the investor fear gauge, Finance Research Letters, 11, 122130

Tse, T., and L. Zhao, 2012, The relationship between currency carry trades and U.S. stocks, Journal of Futures Markets, 32, 252-271

Vähämaa, S., and J. Äijö, 2011, The Fed's policy decisions and implied volatility, Journal of Futures Markets, 31, 995-1010

Whaley, R.E., 2000, The investor fear gauge, Journal of Portfolio Management, Spring, 12-17

Whaley, R.E., 2009. Understanding the VIX. J. Portfolio Management 35, 98-105 

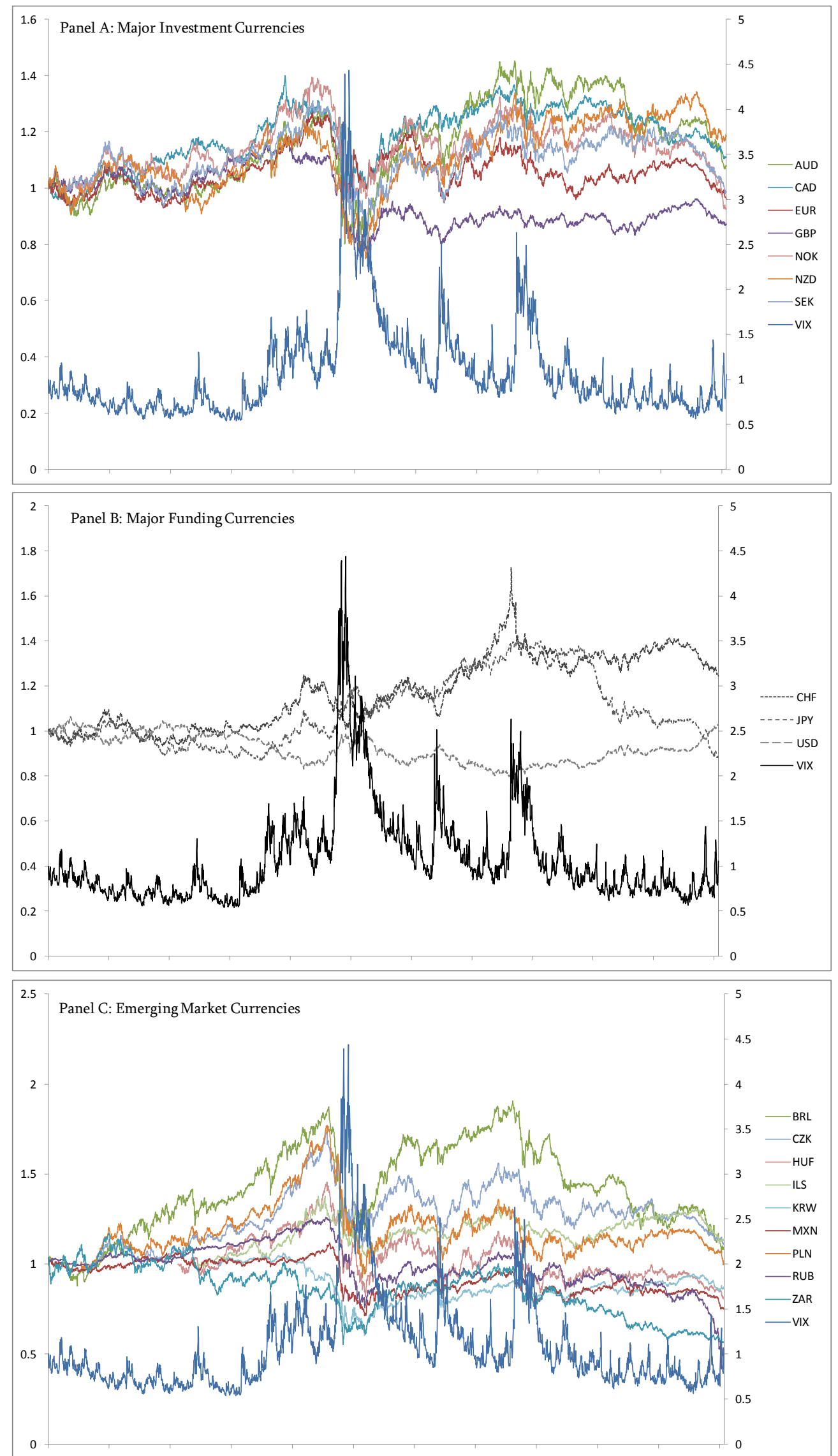

Figure 1. Changes in FX futures and VIX

Note: This figure depicts the evolution of standardised levels in FX futures (left-axis) and VIX (right-axis) over time. Currencies are categorised as major according to the classification of the CME. Major currencies are sub-classified as investment (high-yielding) or funding (low-yielding) according to the average level of interest rates over the sample period. Sample period: March 2004 - December 2014 
Table 1

Theriptive Statistics

\begin{tabular}{|c|c|c|c|c|c|c|c|c|c|c|c|c|c|c|c|c|c|c|c|c|c|}
\hline & \multirow[b]{2}{*}{ VIX } & \multirow[b]{2}{*}{ USD Index } & \multicolumn{7}{|c|}{ Major - Investment } & \multicolumn{2}{|c|}{ Major - Funding } & \multicolumn{10}{|c|}{ Emerging Market } \\
\hline & & & AUD & $\mathrm{CAD}$ & EUR & GBP & NOK & NZD & SEK & CHF & JPY & BRL & CZK & HUF & ILS & KRW & MXN & PLN & RMB & RUB & ZAR \\
\hline \multicolumn{22}{|c|}{ Panel A: Levels } \\
\hline Mean & 20.948 & 94.032 & 0.790 & 0.851 & 1.236 & 1.661 & 0.165 & 0.664 & 0.144 & 0.869 & 0.979 & 0.465 & 0.050 & 0.487 & 0.265 & 0.001 & 0.088 & 0.332 & 0.150 & 0.030 & 0.128 \\
\hline Std. Dev. & 9.010 & 12.813 & 0.167 & 0.132 & 0.183 & 0.172 & 0.013 & 0.135 & 0.011 & 0.177 & 0.145 & 0.092 & 0.006 & 0.057 & 0.018 & 0.000 & 0.011 & 0.040 & 0.011 & 0.271 & 0.022 \\
\hline Maximum & 80.86 & 124.94 & 1.094 & 1.084 & 1.596 & 2.106 & 0.201 & 0.877 & 0.170 & 1.400 & 1.321 & 0.651 & 0.069 & 0.688 & 0.310 & 0.001 & 0.111 & 0.491 & 0.164 & 0.070 & 0.177 \\
\hline Minimum & 9.890 & 75.535 & 0.479 & 0.620 & 0.830 & 1.368 & 0.133 & 0.394 & 0.108 & 0.550 & 0.743 & 0.250 & 0.038 & 0.382 & 0.220 & 0.001 & 0.064 & 0.257 & 0.126 & 0.023 & 0.074 \\
\hline 10-Year IRS & - & 4.215 & 5.691 & 4.189 & 3.738 & 4.325 & 4.822 & 6.125 & 4.042 & 2.577 & 1.349 & 16.568 & 3.850 & 6.697 & 4.574 & 4.464 & 8.030 & 5.244 & 4.378 & 8.788 & 9.202 \\
\hline \multicolumn{22}{|c|}{ Panel B: Returns } \\
\hline Mean & -0.007 & -0.002 & 0.006 & 0.006 & 0.005 & -0.001 & -0.003 & 0.010 & 0.000 & 0.012 & -0.004 & -0.010 & 0.004 & -0.010 & 0.006 & -0.006 & -0.011 & 0.001 & 0.012 & -0.017 & -0.017 \\
\hline Std. Dev. & 6.405 & 0.445 & 0.867 & 0.581 & 0.638 & 0.581 & 0.816 & 0.866 & 0.825 & 0.700 & 0.654 & 1.086 & 0.831 & 1.091 & 0.558 & 0.893 & 0.667 & 1.009 & 0.171 & 0.785 & 1.125 \\
\hline Skewness & 0.65 & -0.24 & -0.77 & -0.10 & -0.08 & -0.38 & -0.31 & -0.52 & 0.13 & -0.43 & 0.22 & -0.67 & -0.30 & -0.37 & -0.37 & 0.41 & -0.61 & -0.41 & 0.26 & -1.66 & -0.40 \\
\hline Kurtosis & 6.97 & 6.72 & 12.70 & 7.70 & 4.40 & 6.63 & 6.00 & 6.15 & 7.84 & 12.43 & 7.14 & 11.26 & 6.62 & 5.59 & 7.26 & 28.19 & 10.05 & 7.07 & 28.96 & 63.11 & 9.87 \\
\hline Jarque-Bera & 2741 & 2208 & 15169 & 3481 & 314 & 2160 & 1052 & 1730 & 2638 & 14106 & 2729 & 11011 & 1476 & 678 & 1697 & 55221 & 8041 & 1891 & 59036 & 56981 & 7524 \\
\hline Observations & 2714 & 2714 & 2714 & 2714 & 2714 & 2714 & 2697 & 2714 & 2697 & 2714 & 2714 & 2714 & 2636 & 2236 & 2179 & 2087 & 2714 & 2637 & 2101 & 2714 & 2714 \\
\hline
\end{tabular}

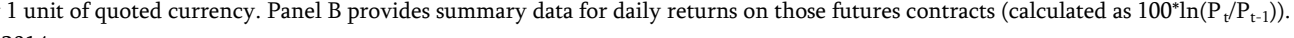

Samp Period: 26 March 2004 - 31 Dec 2014 
Table 2

Regression: Relationship between returns on FX futures and VIX

\begin{tabular}{|c|c|c|c|c|c|c|c|c|c|c|c|c|c|c|c|c|c|c|c|c|}
\hline \multirow{4}{*}{ Constant } & \multicolumn{14}{|c|}{ Major Investing } & \multicolumn{6}{|c|}{ Major Funding } \\
\hline & \multicolumn{2}{|l|}{ AUD } & \multicolumn{2}{|l|}{ CAD } & EUR & \multicolumn{3}{|c|}{ GBP } & \multicolumn{2}{|l|}{ NOK } & \multicolumn{2}{|l|}{ NZD } & \multicolumn{2}{|l|}{ SEK } & \multicolumn{2}{|l|}{$\mathrm{CHF}$} & \multicolumn{2}{|l|}{ JPY } & \multicolumn{2}{|l|}{ USD } \\
\hline & 0.005 & & 0.006 & & 0.005 & & -0.001 & & -0.003 & & 0.010 & & 0.000 & & 0.012 & & -0.004 & & -0.002 & \\
\hline & 0.013 & & 0.008 & & 0.011 & & 0.010 & & 0.014 & & 0.013 & & 0.014 & & 0.011 & & 0.010 & & 0.007 & \\
\hline \multirow[t]{2}{*}{$\mathrm{R}(\mathrm{VIX})$} & -0.038 & $* * *$ & -0.024 & $* * *$ & -0.010 & $* * *$ & -0.009 & $* * *$ & -0.027 & $* * *$ & -0.034 & $* * *$ & -0.027 & $* * *$ & 0.005 & $* *$ & 0.021 & $* * *$ & 0.005 & $* * *$ \\
\hline & 0.007 & & 0.003 & & 0.004 & & 0.003 & & 0.004 & & 0.006 & & 0.005 & & 0.003 & & 0.004 & & 0.001 & \\
\hline Adj. R2 & 0.079 & & 0.072 & & 0.010 & & 0.010 & & 0.052 & & 0.064 & & 0.051 & & 0.002 & & 0.042 & & 0.005 & \\
\hline D-W & 2.155 & & 2.113 & & 2.005 & & 1.981 & & 2.012 & & 2.007 & & 2.055 & & 2.047 & & 2.062 & & 2.054 & \\
\hline AIC & 2.472 & & 1.677 & & 1.930 & & 1.741 & & 2.380 & & 2.485 & & 2.401 & & 2.123 & & 1.946 & & 1.213 & \\
\hline Wald F-Statistic & 33.60 & & 52.70 & & 7.69 & & 12.35 & & 40.98 & & 38.71 & & 36.58 & & 2.14 & & 26.73 & & 16.63 & \\
\hline \multirow[t]{3}{*}{ Observations } & 2714 & & 2714 & & 2714 & & 2714 & & 2697 & & 2714 & & 2697 & & 2714 & & 2714 & & 2714 & \\
\hline & \multicolumn{20}{|c|}{ Emerging Market } \\
\hline & BRL & & CZK & & HUF & & ILS & & KRW & & MXN & & PLN & & RMB & & RUB & & ZAR & \\
\hline \multirow[t]{2}{*}{ Constant } & -0.011 & & 0.004 & & -0.008 & & 0.006 & & -0.006 & & -0.011 & & 0.001 & & 0.012 & **** & -0.017 & & $\begin{array}{l}-0.02 \\
\end{array}$ & \\
\hline & 0.016 & & 0.016 & & 0.023 & & 0.012 & & 0.018 & & 0.010 & & 0.018 & & 0.003 & & 0.013 & & 0.02 & \\
\hline \multirow[t]{2}{*}{$\mathrm{R}(\mathrm{VIX})$} & -0.047 & $* * *$ & -0.027 & $* * *$ & -0.053 & $* * *$ & -0.017 & $* * *$ & -0.026 & $* * *$ & -0.041 & $* * *$ & -0.047 & $* * *$ & -0.002 & $* * *$ & -0.026 & $* * *$ & -0.05 & $* * *$ \\
\hline & 0.005 & & 0.005 & & 0.006 & & 0.002 & & 0.007 & & 0.004 & & 0.006 & & 0.001 & & 0.005 & & 0.00 & \\
\hline Adj. R2 & 0.078 & & 0.050 & & 0.122 & & 0.051 & & 0.042 & & 0.157 & & 0.101 & & 0.010 & & 0.044 & & 0.067 & \\
\hline D-W & 2.119 & & 1.992 & & 2.011 & & 1.944 & & 2.136 & & 2.064 & & 2.019 & & 2.316 & & 1.932 & & 2.080 & \\
\hline AIC & 2.922 & & 2.418 & & 2.883 & & 1.621 & & 2.570 & & 1.859 & & 2.749 & & -0.706 & & 2.309 & & 3.005 & \\
\hline Wald F-Statistic & 78.27 & & 30.25 & & 91.59 & & 63.48 & & 15.05 & & 97.86 & & 62.86 & & 7.87 & & 25.36 & & 88.24 & \\
\hline Observations & 2714 & & 2636 & & 2236 & & 2179 & & 2087 & & 2714 & & 2637 & & 2101 & & 2714 & & 2714 & \\
\hline
\end{tabular}

independet variable is the daily return on the CBOE implied volatility index (VIX). Currencies are categorised as major or emerging market according to the CME classification system. Major currencies are subdivided into investing and funding currencies on the basis of average levels of interest rates over the sample period. Newey-West standard errors are reported in parentheses.

Sample Period: 26 March 2004 - 31 Dec 2014

${ }^{* * *},{ }^{* *},{ }^{*}$ denote significance at the $1 \%, 5 \%$ and $10 \%$ levels respectively. 
Table 3

Identifying break points

\begin{tabular}{cccc}
\hline & & Break 1 & Break 2 \\
\hline & USD Index & 30-Sep-08 & 26-Sep-12 \\
& AUD & 22-Sep-08 & 26-Jul-12 \\
& CAD & 30-Sep-08 & 9-Aug-12 \\
Major - & EUR & 30-Sep-08 & 3-Aug-12 \\
Investment & GBP & 30-Sep-08 & 9-Aug-12 \\
& NOK & 30-Sep-08 & 1-Jun-12 \\
& NZD & 30-Sep-08 & 21-Sep-12 \\
Major - & SEK & 30-Sep-08 & 21-May-12 \\
Funding & CHF & 30-Sep-08 & 26-Sep-12 \\
& JPY & 1-Jul-08 & 14-Sep-12 \\
& BRL & 9-Aug-08 & 20-May-12 \\
& CZK & 30-Sep-08 & 3-Aug-12 \\
& HUF & 30-Sep-08 & 3-Aug-12 \\
& ILS & 15-Sep-08 & 15-May-12 \\
Emerging & KRW & 15-Sep-08 & 23-Jul-12 \\
Market & MXN & 28-Aug-08 & 3-Aug-12 \\
& PLN & 30-Sep-08 & 6-Nov-12 \\
& RMB & 1-Jul-08 & 12-Nov-12 \\
& RUB & 30-Sep-08 & 21-Sep-12 \\
& ZAR & 17-Sep-08 & 9-Aug-12 \\
\hline Note: This
\end{tabular}

Note: This table reports break points for the regression specified in Equation (1), determined using the sequential break-point tests of Bai (1997) and Bai and Perron (1998).

Sample Period: 26 March 2004 - 31 Dec 2014 
Table 4

Regression: Relationship between returns on FX futures and VIX during financial crisis

\begin{tabular}{|c|c|c|c|c|c|c|c|c|c|c|c|c|c|c|c|c|c|c|c|c|}
\hline \multirow{2}{*}{$\begin{array}{l}\text { Panel B: Global } \\
\text { Financial Crisis }\end{array}$} & \multicolumn{14}{|c|}{ Major Investing } & \multicolumn{6}{|c|}{ Major Funding } \\
\hline & AUD & & CAD & & EUR & & GBP & & NOK & & NZD & & SEK & & CHF & & JPY & & USD & \\
\hline \multirow[t]{2}{*}{ Constant } & -0.018 & & -0.040 & & -0.010 & & -0.048 & & -0.042 & & -0.041 & & -0.045 & & 0.010 & & 0.035 & & 0.007 & \\
\hline & 0.057 & & 0.050 & & 0.048 & & 0.051 & & 0.051 & & 0.067 & & 0.057 & & 0.047 & & 0.040 & & 0.033 & \\
\hline \multirow{2}{*}{$\mathrm{R}(\mathrm{VIX})$} & -0.091 & $* * *$ & -0.048 & $* * *$ & -0.015 & $* * *$ & -0.022 & ** & -0.038 & $* * *$ & -0.078 & $* * *$ & -0.036 & $* * *$ & 0.020 & $* * *$ & 0.061 & $* * *$ & 0.015 & ${ }^{* * *}$ \\
\hline & 0.015 & & 0.009 & & 0.007 & & 0.009 & & 0.010 & & 0.012 & & 0.009 & & 0.008 & & 0.007 & & 0.005 & \\
\hline Adj. R2 & 0.164 & & 0.123 & & 0.014 & & 0.027 & & 0.043 & & 0.157 & & 0.038 & & 0.023 & & 0.229 & & 0.026 & \\
\hline $\mathrm{D}-\mathrm{W}$ & 2.355 & & 2.048 & & 1.929 & & 1.798 & & 2.069 & & 2.090 & & 2.077 & & 2.040 & & 2.077 & & 1.978 & \\
\hline AIC & 3.648 & & 2.724 & & 2.646 & & 2.748 & & 3.342 & & 3.390 & & 3.384 & & 2.756 & & 2.451 & & 1.999 & \\
\hline Wald F-Statistic & 37.94 & & 28.73 & & 4.08 & & 5.84 & & 13.61 & & 45.39 & & 15.52 & & 6.84 & & 79.20 & & 7.46 & \\
\hline \multirow[t]{3}{*}{ Observations } & 983 & & 983 & & 983 & & 983 & & 983 & & 983 & & 983 & & 983 & & 983 & & 983 & \\
\hline & \multicolumn{20}{|c|}{ Emerging Market } \\
\hline & BRL & & CZK & & HUF & & ILS & & KRW & & MXN & & PLN & & RMB & & RUB & & ZAR & \\
\hline \multirow[t]{2}{*}{ Constant } & -0.020 & & -0.004 & & -0.030 & & -0.005 & & -0.079 & & -0.046 & & -0.065 & & 0.018 & ${ }^{*}$ & -0.066 & & $\begin{array}{l}-0.028 \\
\end{array}$ & \\
\hline & 0.054 & & 0.068 & & 0.082 & & 0.049 & & 0.073 & & 0.058 & & 0.069 & & 0.009 & & 0.058 & & 0.066 & \\
\hline \multirow[t]{2}{*}{ R(VIX) } & -0.096 & $* * *$ & -0.033 & $* * *$ & -0.070 & $* * *$ & -0.021 & $* * *$ & -0.064 & $* * *$ & -0.073 & $* * *$ & -0.059 & $* * *$ & -0.005 & $* *$ & -0.035 & $* *$ & -0.090 & ${ }^{* * *}$ \\
\hline & 0.014 & & 0.011 & & 0.011 & & 0.006 & & 0.013 & & 0.014 & & 0.012 & & 0.003 & & 0.015 & & 0.013 & \\
\hline Adj. R2 & 0.183 & & 0.032 & & 0.106 & & 0.029 & & 0.073 & & 0.220 & & 0.074 & & 0.023 & & 0.044 & & 0.155 & \\
\hline $\mathrm{D}-\mathrm{W}$ & 2.142 & & 1.990 & & 1.892 & & 1.983 & & 2.140 & & 2.060 & & 1.947 & & 2.232 & & 2.053 & & 2.162 & \\
\hline AIC & 3.633 & & 3.374 & & 3.631 & & 2.643 & & 3.854 & & 2.848 & & 3.684 & & 0.125 & & 3.195 & & 3.701 & \\
\hline Wald F-Statistic & 48.34 & & 8.48 & & 43.40 & & 10.94 & & 24.13 & & 27.44 & & 26.11 & & 4.14 & & 5.53 & & 45.25 & \\
\hline Observations & 983 & & 983 & & 983 & & 983 & & 983 & & 983 & & 983 & & 983 & & 983 & & 983 & \\
\hline
\end{tabular}

Note: This table reports the regression estimates for the model specified in equation (1), where the dependent variable is the daily return on a particular FX future, and the independet variable is the daily return on the CBOE implied volatility index (VIX). Currencies are categorised as major or emerging market according to the CME classification system. Major currencies are subdivided into investing and funding currencies on the basis of average levels of interest rates over the sample period. Newey-West standard errors are reported in parentheses.

Sample Period: 15 September 2008 - 03 August 2012 for global financial crisis

${ }^{* * *},{ }^{* *},{ }^{*}$ denote significance at the $1 \%, 5 \%$ and $10 \%$ levels respectively. 